九州大学学術情報リポジトリ

Kyushu University Institutional Repository

\title{
NEW LONGICORN-BEETLES OF THE RYUKYUS AND TAIWAN (COLEOPTERA : CERAMBYCIDAE)
}

Makihara, Hiroshi

https://doi.org/10.5109/2380

出版情報 : ESAKIA. 12，pp.49-62，1978-11-30. Entomological Laboratory， Faculty of Agriculture， Kyushu University

バージョン :

権利関係 : 


\title{
NEW LONGICORN-BEETLES OF THE RYUKYUS AND TAIWAN (COLEOPTERA: CERAMBYCIDAE)*
}

\author{
H IROSHI M AKIHARA \\ Entomological Laboratory, Faculty of Agriculture \\ Kyushu University, Fukuoka 812, Japan
}

\begin{abstract}
A bstract
Three new species, Encyclops viridipennis, Bumetopia brevicornis and Glenea masakii and two new subspecies, Thranius multinotatus okinawensis and Penthides fiavus multipubens are described from the Ryukyus and Taiwan.
\end{abstract}

In the present paper, I describe three new species, Encyclops viridipennis from Taiwan, Bumetopia brevicornis from Ishigaki I. of the Ryukyus and Glenea masakii from Uotsurijima I. of the Ryukyus, and two new subspecies Thranius multinotatus okinawensis from Okinawa I. of the Ryukyus and Penthides flavus multipubens from Ishigaki I. and Iriomote I. of the Ryukyus.

I wish to express my sincere gratitude to Professor Y. Hirashima and Associate Professor K. Morimoto of Kyushu University for their continuous guidans. My thanks are due to Dr. M. Hayashi of Osaka Jonan Women's College, Associate Professor M. Sato of Nagoya Women's College, Mr. M. Ohbayashi of Kanagawa Horticultural Experiment Station, Mr. T. Kumata of Hokkaido University, Mr. A. Nagai of Omiya High School and T. Takakuwa of Tokyo for the donation or the loan of the valuable specimens as well as the type specimen for my present study, and I indebted to Professor T. Uchida and Mr. T. Mohri of Kyushu University for their kind favor and permissions to use the Scanning Electron Microscope HITACHI-SSM 2.

\section{Subfamily LEPTURINAE \\ Tribe ENCY CLOPINI}

\section{Encyclops viridipennis sp. nov.}

Body black; antenna blackish brown, apical parts of segments 2-4 reddish brown; labrum reddish brown; apices of apical segments of palpi dark reddish

* Contribution from the Entomological Laboratory, Faculty of Agriculture, Kyushu University, Fukuoka (Ser. 3, No. 53). 
brown; elytra metallic golden green; claws reddish brown.

Body slender and subparallel.

Head broad and deeply punctured, tempora subparallel, constricted at neck, with long erect hairs and sparse, short oblique hairs; occiput weakly convex, with dense, curved and depressed golden yellow pubescence and with sparse erect hairs except for basal triangular part; vertex very narrow and distinctly v-shaped, with sparse, depressed golden yellow pubescence ; frons flat, oblong and right angled to occiput, with sparse, depressed whitish yellow pubescence ; mouth parts with sparse, oblique whitish yellow hairs; apical parts of maxillary palpi dolabriform; eyes large, inferior eye lobes two times as long as gena ; antenna as long as body, relative length of each segment as follows : 1.3 : $0.3: 2.1: 1.9: 2.8: 2.3: 2.1: 1$. $8: 1$. $6: 1.4: 1.7$, segment 2 with short oblique white hairs, segments $3-11$ with short hairs and oblique white pubescence and hairs becoming denser towards apical segments.

Pronotum slightly longer than broad, median portion of lateral margin obtusely tuberculate ; apex constricted, weakly impressed transversely ; base broad, but narrower than tuberculate median portion, broadly impressed; disk slightly convex, densely and deeply punctured, with dense, curved and depressed golden yellow pubescence except for apical and basal portions, and with sparse yellow hairs.

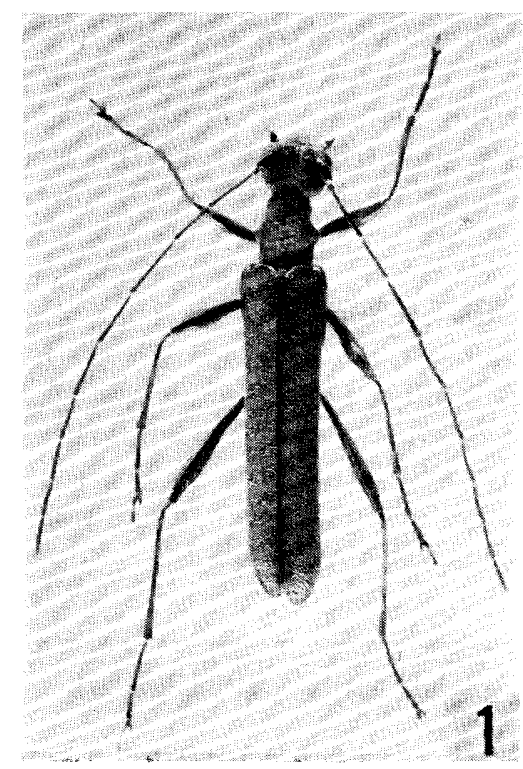

Fig. 1. Encyclops viridipennis sp. nov.

Scutellum slender, triangular, uneven and intricate, with short depressed white pubescence.

Elytra subparallel, slightly tapering posteriorly, about four times as long as broad; basal part wide and middle part narrow; apices rounded ; disk slightly convex and shining, finely punctured and punctures becoming denser toward 
apex, with sparse, long and short, oblique white hairs.

Legs slender ; femora with sparse, oblique white and brown hairs; tibiae with sparse oblique whitish yellow hairs dorsally, apical halves with sparse, short oblique yellowish brown hairs, apices with oblique yellowish brown setae; two spines at ventral sides of mid tibiae; dorsal faces of tarsi with sparse, oblique whitish yellow hairs, ventral faces of tarsi with erect dense white pubescence.

Gula with sparse, erect white hairs; prosternum with sparse, erect white hairs in addition to depressed whitish yellow pubescence except for apical portion; mesosternum and metepimeron with not dense, depressed whitish yellow pubescence.

Abdominal sternites 3-7 equal in length to each other, with sparse, oblique white hairs and depressed pubescence; apex of sternite 7 with dense, oblique golden yellow hairs.

Length: $9.5 \mathrm{~mm}$. Width $: 1.8 \mathrm{~mm}$.

Distribution : Taiwan.

Type material: Holotype $\precsim$ (Type No. 2124, Kyushu Univ.), HohuanchiSungchuangkang (about $2500 \mathrm{~m}$ above the sea-level), Nantou Hsien, Taiwan, 25. vi. 1976, H. Makihara leg.

Type depository: The holotype is preserved in the collection of the Entomological Laboratory, Faculty of Agriculture, Kyushu University.

Diagnosis: This new species is related to E.olivacea Bates from Japan, but differs from it by the following points: Vertex narrow and v-shaped ; head and pronotum with depressed golden yellow pubescence; body with long erect and oblique white hairs; elytra metallic golden green; antennae, legs and palpi black.

Note: This new species was collected on the flowers of Quercus sp.

\section{Subfamily CERAMBYCINAE}

\section{Tribe ThRANIINI}

\section{Thranius multinotatus okinawensis subsp. nov.}

Diagnosis: This new subspecies is similar to T. multinotatus latipennis Hayashi from Ishigaki I. and Iriomote I. of the Ryukyus and T. multinotatus signatus Schwarzer from Taiwan, but separable from them by the following key.

$$
\text { Key to three subspecies of } T \text {. multinotatus Pic }
$$

1. Apices of elytra narrow; pronotum strongly convex in female ; body large

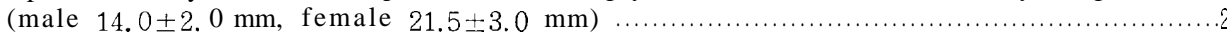

- Apices of elytra wide ; pronotum not strongly convex in female; body small (male $11.0 \pm 2.0 \mathrm{~mm}$, female $14.0 \mathrm{~mm}$ ) ; lateral lobes of male genitalia very short, roof long; Ishigaki I. and Iriomote I.......... T. multinotatus latipennis Hayashi

2. Brown markings of elytra large; middle parts of elytra not narrow; basal parts of elytra weakly concave; ventral part of body with golden yellow pu- 
bescence ; lateral lobes of male genitalia very short, roof short; Okinawa I.

T. multinotatus okinawensis subsp. nov.

- Brown markings of elytra small; middle parts of elytra narrow; basal parts of elytra strongly concave; ventral part of body with silver grey pubescence;

lateral lobes of male genitalia not short, roof slender and long; Taiwan.........

..T. multinotatus signatus Schwarzer

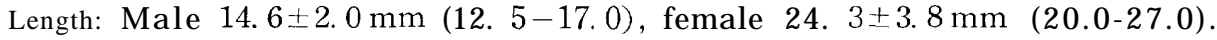
Distribution : Okinawa I. of the Ryukyus.

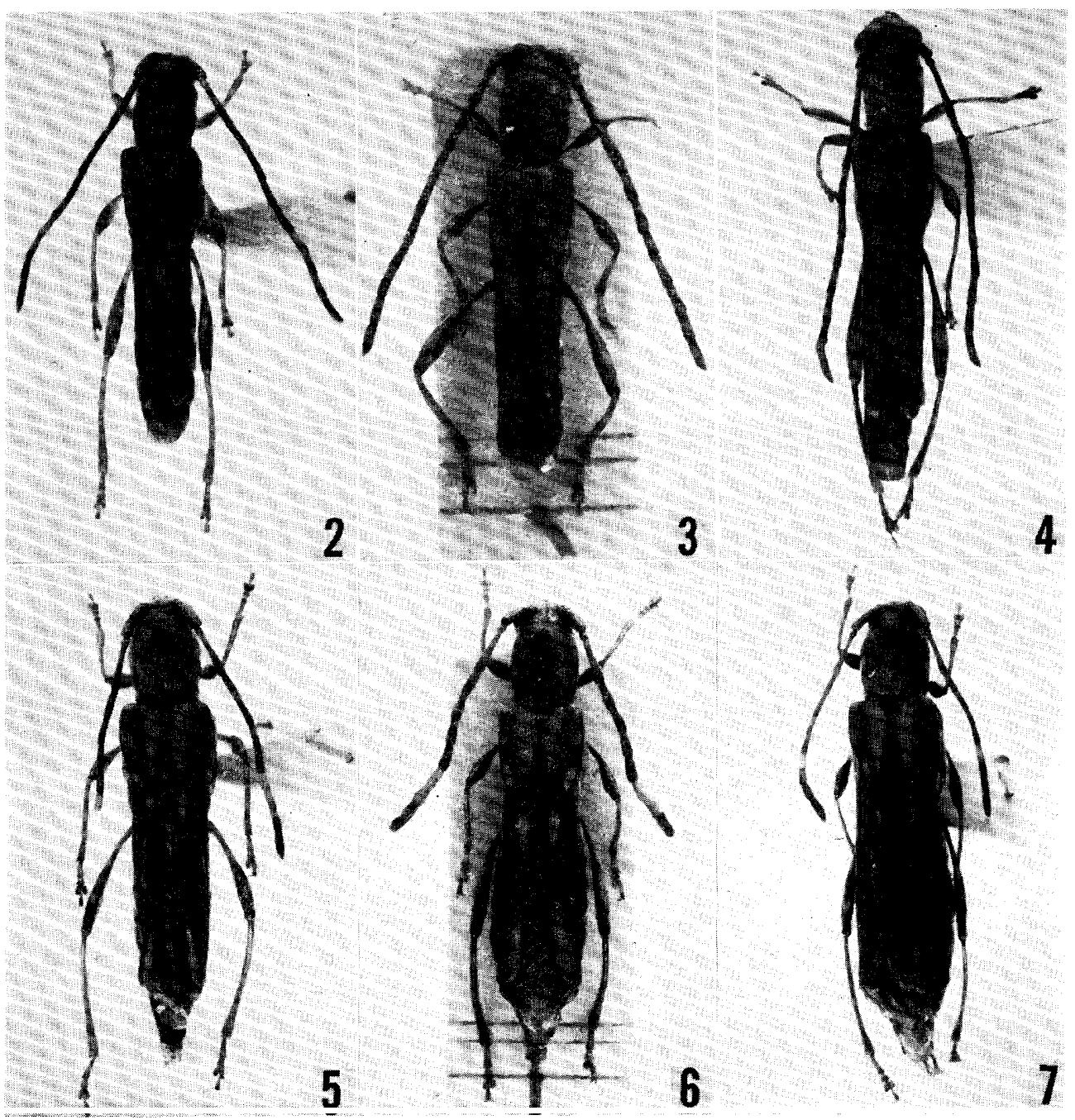

Figs. 2-7. Three subspecies of Thranius multinotatus. 2: T. multinotatus okinawensis subsp. nov., male. $3:$ T. multinotatus latipennis, male. $4:$ T. multinotatus signatus, male. $5:$ T. multinotatus okinawensis subsp. nov., female. $6:$ T. multinotatus latipennis, female. $7:$ T. multinotatus signatus, female. 

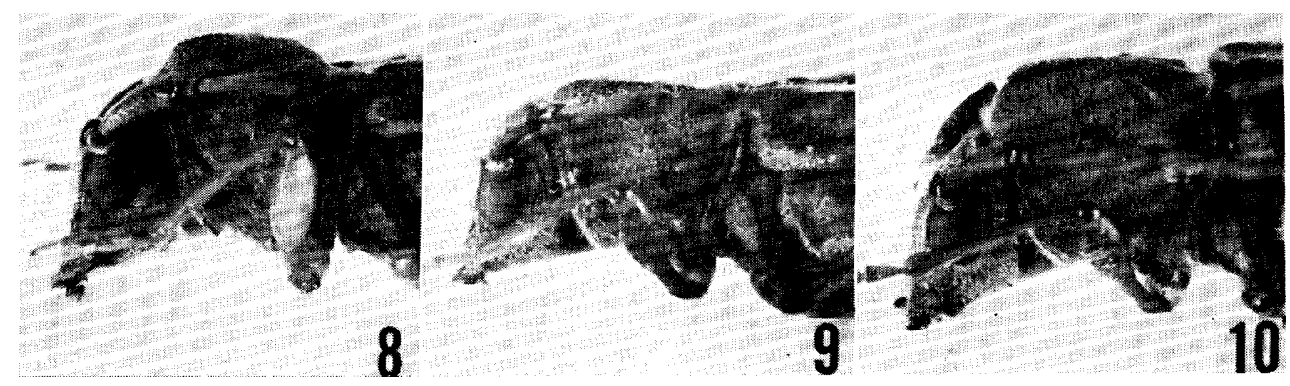

Figs. 8-10. Prothorax of Thranius multinotatus, female, lateral, view. 8: T. multinotatus okinawensis subsp. nov. 9: T. multinotatus latipennis. 10: T. multinotatus signatus.
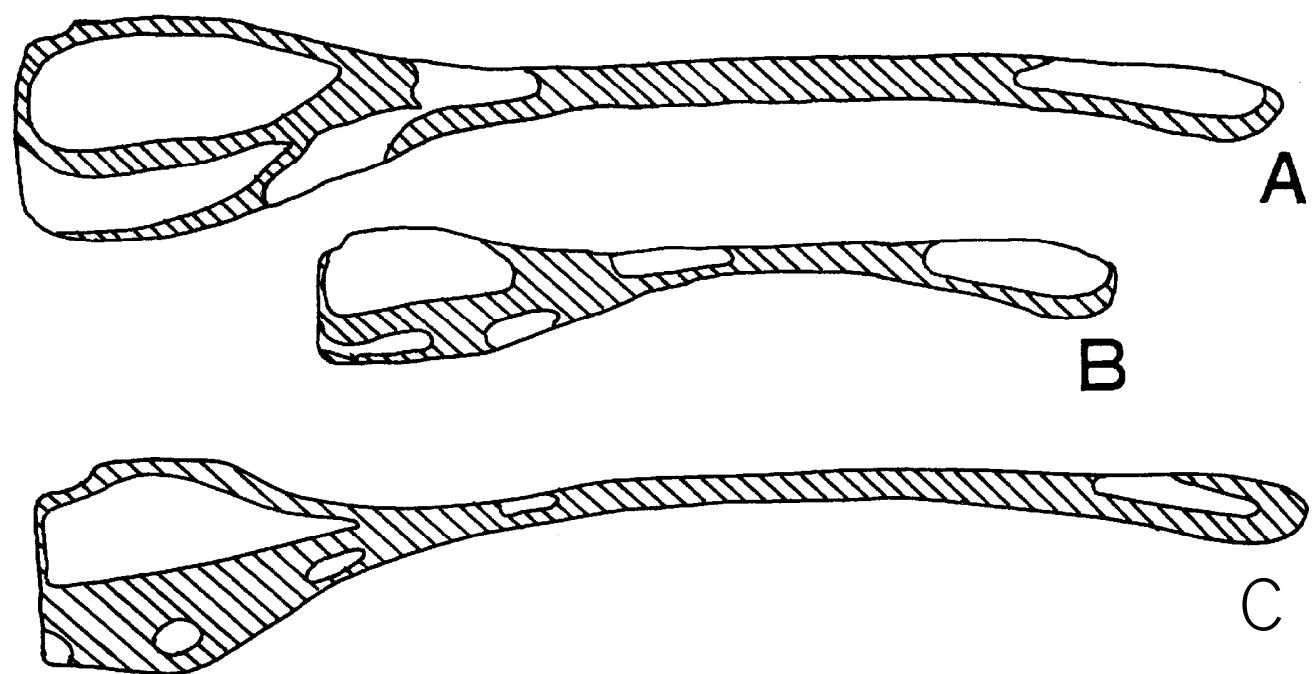

Fig. 11. Elytral markings of Thranius multinotatus, female. A: T. multinotatus okinawensis subsp. nov., B: T. multinotatus latipennis, C: T. multinotatus signatus.

Type material: Holotype $\precsim$ (Type No. 2125, Kyushu Univ.), Oku, Okinawa I. of the Ryukyus, 16. v. 1978, H. Makihara leg. Paratypes :2むむ, Mt. Yonaha, Okinawa I. of the Ryukyus, 2. vi. 1974, H. Irie leg.; 오, same locality and collector as above, 3. vi. 1974; 우, Oku, Okinawa I. of the Ryukyus, 16. v. 1978, H. Makihara leg. ; 우, same locality and collector as above, 17. v. 1978.

Type depository: The holotype is preserved in the collection of the Entomological Laboratory, Faculty of Agriculture, Kyushu University.

Note: One female was collected on a fallen tree trunk of Mallotus japonicus (Thumb.), Euphorbiaceae, in the state of the oviposition, and one male was collected by the sweeping of the bush. 


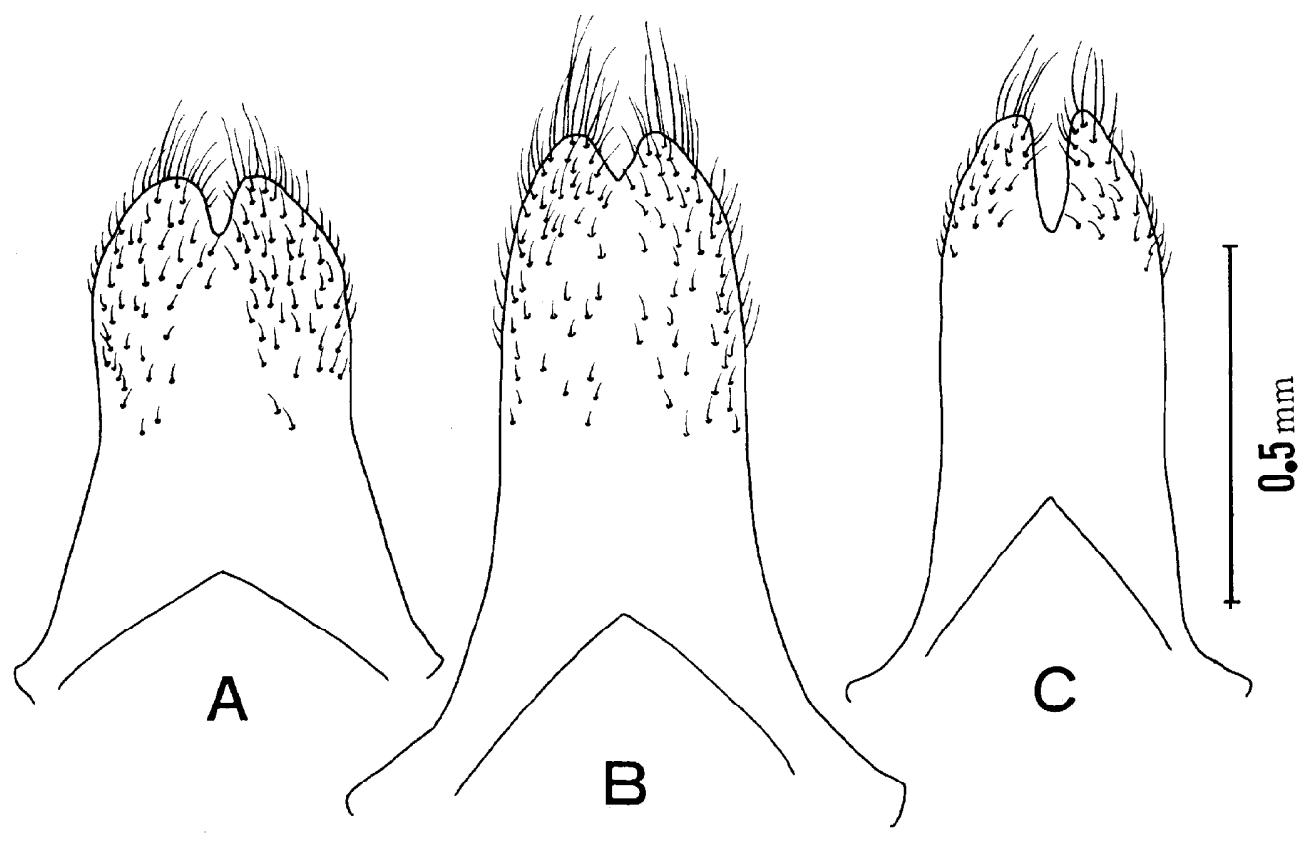

Fig. 12. Thranius multinotatus, lateral lobes of male genitalia, ventral view. A: T. multinotatus okinawensis subsp. nov., B: T. multinotatus latipennis, C: T. multinotatus signatus.

\section{Subfamily LAMIINAE}

\section{Tribe HomonoeinI}

\section{Bumetopia brevicornis sp. nov.}

Body oval and small, reddish brown.

Head broad and deeply punctured, with depressed greyish white pubescence; frons with sparse, oblique whitish yellow hairs at apex; eyes small, relative length of inferior eye lobes to gena $0.47 \pm 0.08$ (male), $0.54 \pm 0.04$ (female) ; labrum with sparse, oblique whitish yellow hairs at apices, with sparse greyish white pubescence; mandibles with sparse, depressed whitish yellow pubescence at basal halves; palpi with sparse, oblique whitish yellow hairs ; antennae short, relative length to body $1.01 \pm 0.05$ (male), $0.74 \pm 0.02$ (female), relative length of each segment as follows (mean) : $11.9: 2.4: 17.3: 15.1: 9.3$ : 8. 5 : 7. $5: 6.9: 6.6: 6.0: 6.5$ (male), $13.4: 2.9: 20.5: 15.2: 9.6: 8.1: 7.1: 6.4$ : $5.8: 5.3: 5.7$ (female), with depressed greyish white pubescence, apex of segment 2 and segments 3-11 with sparse white hairs.

Pronotum oblong, relative length of base to length of pronotum $0.93 \pm 0.04$ (male), $0.87 \pm 0.04$ (female), relative length of base to apex $1.07 \pm 0.04$ (male), $0.99 \pm 0.02$ (female), not deeply punctured, with two lateral tubercles at middle, with dense, fine depressed silver grey pubescence, and with sparse, oblique or erect silver grey hairs. 
Scutellum small and semicircular, with dense, fine, depressed silver grey pubescence.

Elytra subparallel at basal half, narrower at apical half, relative length of width to length $2.08 \pm 0.07$ (male), 1.98 \pm 0.09 (female), apices truncate subroundly, not deeply punctured, with fine, depressed silver grey pubescence, and with sparse, oblique silver grey hairs.
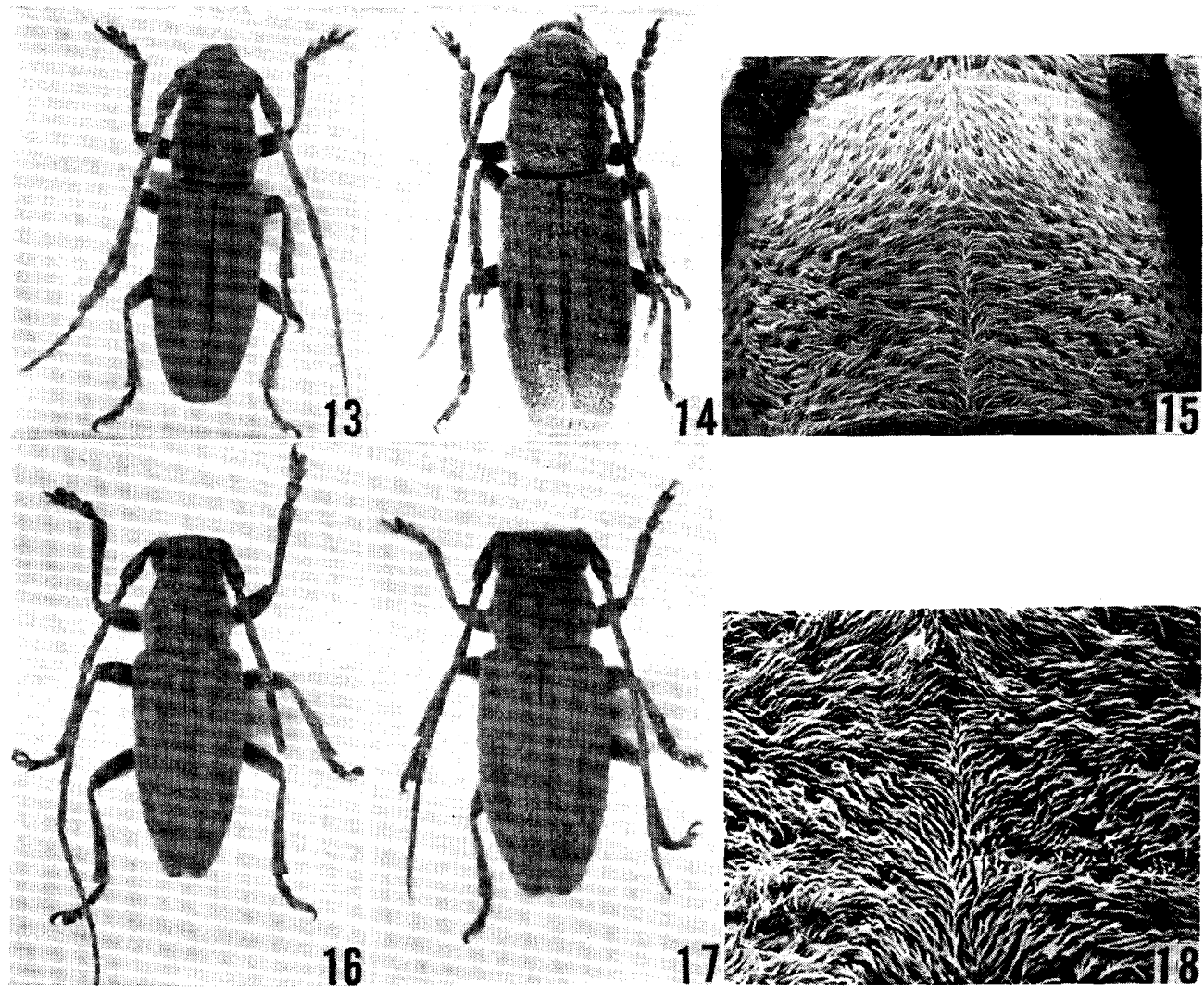

Figs. 13-15. Bumetopia brevicornis sp. nov. 13: male. 14: female. 15: male pronotum (photo by scanning electron microscope, $\times 50$ ).

Figs. 16-18. Bumelopia sakishimana ishigaki. 16: male. 17: female. 18: male pronotum (photo by scanning electron microscope, $\times 50$ ).

Hind wings reduced and short, relative length of body to their length 0. $306 \pm 0.019$ (male), 0. $288 \pm 0.021$ (female).

Legs short, relative length of body to fore tibia $0.217 \pm 0.010$ (male), 0.187 \pm 0.006 (female) ; femora with depressed greyish white pubescence ; fore tibiae with dense, oblique greyish white hairs on insides, and yellowish brown setae at apices; mid and hind tibiae with depressed greyish white pubescence, oblique greyish white hairs, dense oblique yellowish brown hairs on outsides of apical halves, yellowish brown setae at apices ; tarsi with sparse, oblique greyish 
white hairs on dorsal sides.

Ventral side with fine, depressed greyish white pubescence.

Male genitalia slender; median lobe with median struts; ventral edge of median orifice sharply pointed; tegmen with long basal piece, roof absent; lateral lobes separated from each other.

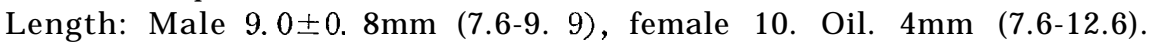

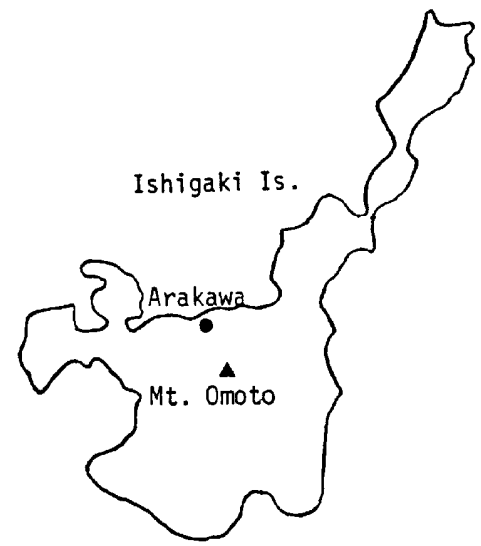

Fig. 19. Map of Ishigaki I. of the Ryukyus.

Distribution: Ishigaki I. (the top of Mt. Omoto and Arakawa) of the Ryukyus.

Type material: Holotype o (Type No. 2126, Kyushu Univ.), The top of Mt. Omoto, Ishigaki I. of the Ryukyus, 12. iv. 1974, H. Makihara leg. Paratypes $\delta^{\star}$, same locality and collector as holotype, 11. iv. 1974; $\precsim \& 5$ 우우, same locality and collector as above, 12. iv. 1974; 3 우오, same locality and collector as above, 14. iv. 1974; $\partial$, same locality and collector as above, 16. vi. 1974; ð\&4우우, same locality and collector as above, 20. vi. 1974; ð, Arakawa, Ishigaki I. of the Ryukyus, 5. vi. 1973, K. Akiyama leg.

Type depository: The holotype is preserved in the collection of the Entomological Laboratory, Faculty of Agriculture, Kyushu University.

Diagnosis: This new species is related to B. sakishimana ishigaki Hayashi from Ishigaki I. and Iriomote I. of the Ryukyus, but separable from it by the following points.

B. brevicornis sp. nov.: Body small, male $9.0 \pm 0.8 \mathrm{~mm}$, female 10. $0 \pm 1.4 \mathrm{~mm}$; antenna short. relative length to body, male $1.01 \pm 0$. 05, female $0.74 \pm 0$. 02; antenna1 segment 1 long, relative length to antenna, male $0.120 \pm 0.008$, female $0.130 \pm 0.005$; elytra without markings ; body with dense fine, silver grey pubescence; apices of elytra rounded.

B. sakishimana ishigaki Hayashi : Body large, male $10.8 \pm 1.0 \mathrm{~mm}$, female $12.2 \pm 1.4 \mathrm{~mm}$; antenna long, relative length to body, male $1.23 \pm 0.06$, female $0.96 \pm 0$. 02 ; antenna1 segment 1 short, relative length to antenna, male $0.105 \pm$ 0.005 , female $0.117 \pm 0$. 006; elytra with markings; body with dense whitish yellow and yellow pubescence; apices of elytra subroundly truncate. 

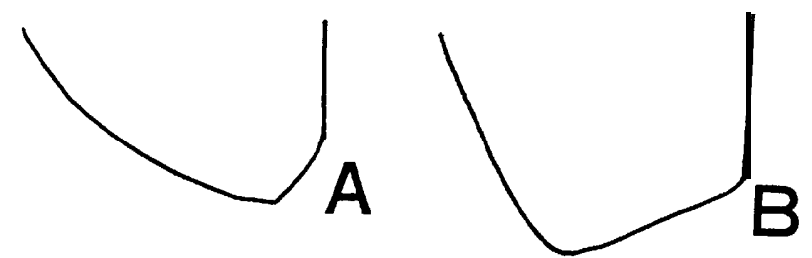

Fig. 20. Elytral apex, A: Bumetopia brevicornis sp. nov., B: B. sakishimana ishigaki.
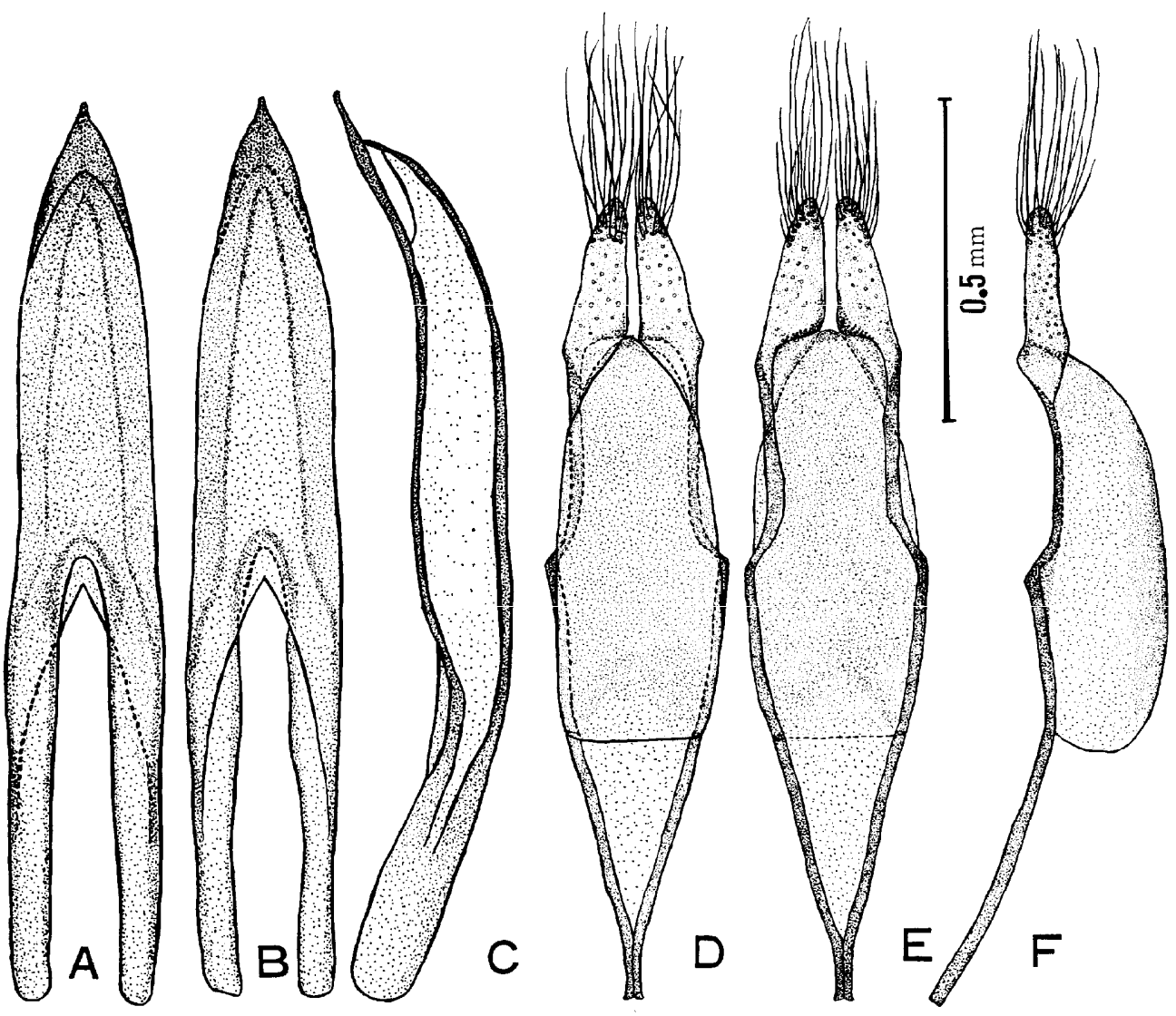

Fig. 21. Male genitalia of Bumetopia brevicornis sp. nov. A-C. median lobe, D-F. lateral lobes and tegmen. A \& D: dorsal view, B \& E: ventral view, C \& F: lateral view.

\section{Tribe RHodopinini}

Penthides flavus multipubens subsp. nov.

Diagnosis: This new subspecies is similar to $\boldsymbol{P}$. flavus flavus Matsushita from Taiwan, but differs from it by the following points : Body blackish brown ; head and pronotum with long pubescence in male; head, pronotum and ely- 


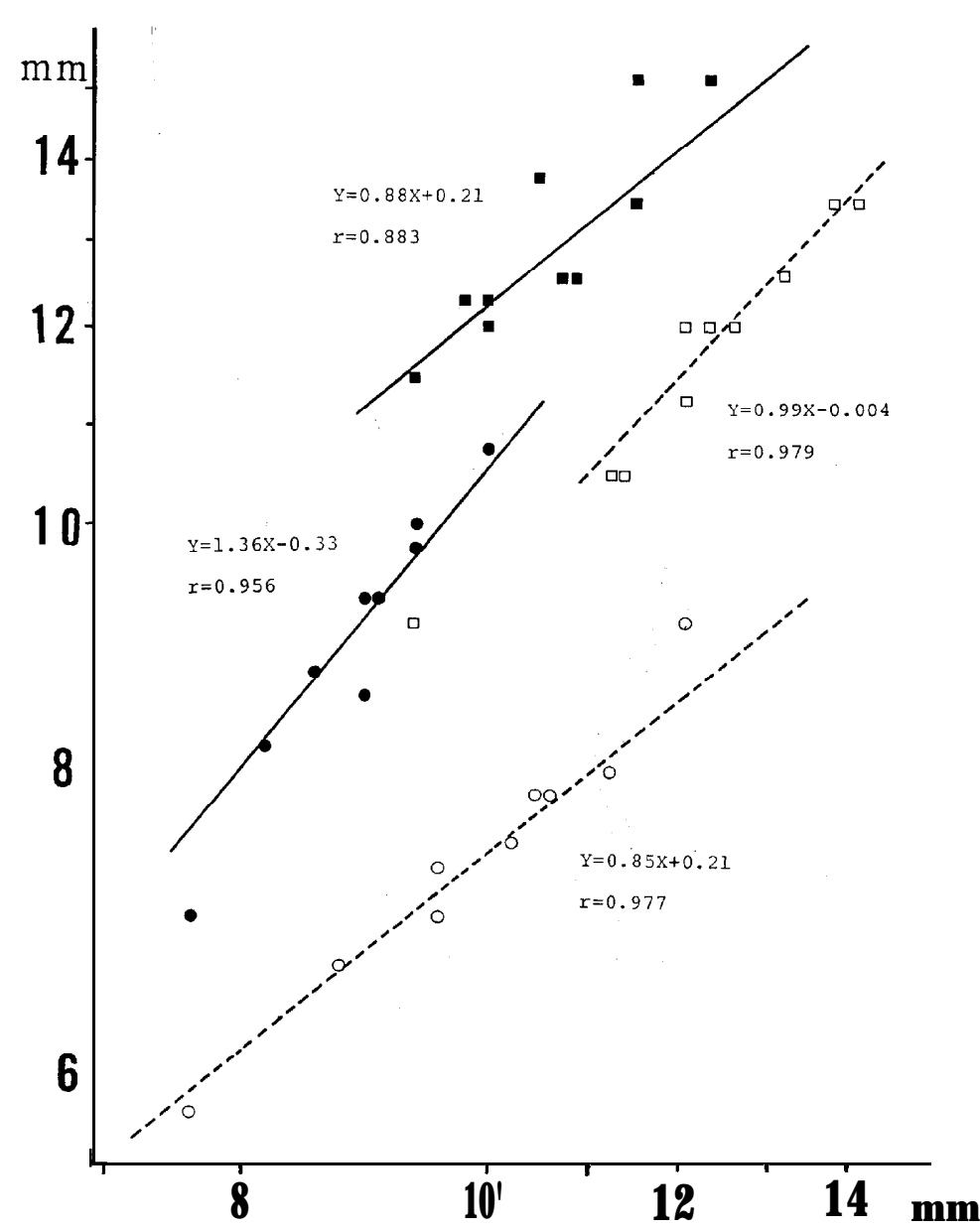

Fig. 22. Correlation of the length between the antenna (the ordinate) and the body (the abscissa) of the two species, Bumetopia brevicornis sp. nov. and B. sakishimana ishigaki in the logarithmic scale. Black dots, B. brevicornis. sp. nov., male; circles, B. brevicornis sp. nov., female ; black squares, B. sakishimana ishigaki, male ; squares, B. sakishimana ishigaki, f e m a $1 \mathrm{e}$.

tra with long pubescence in female; head with sparse, short oblique blackish brown hairs in male; femora with depressed white pubescence.

$$
\text { KeY to the SPEctes of the genus Penthides }
$$

1. Head and prothorax reddish brown; legs with sparse, oblique whitish yellow hairs

- Head and ventral sides of prothorax black or blackish brown; legs with sparse, oblique blackish brown or brown hairs; Honshu, Kyushu, Tokara-Nakanoshima I. and Amami-Oshima I 


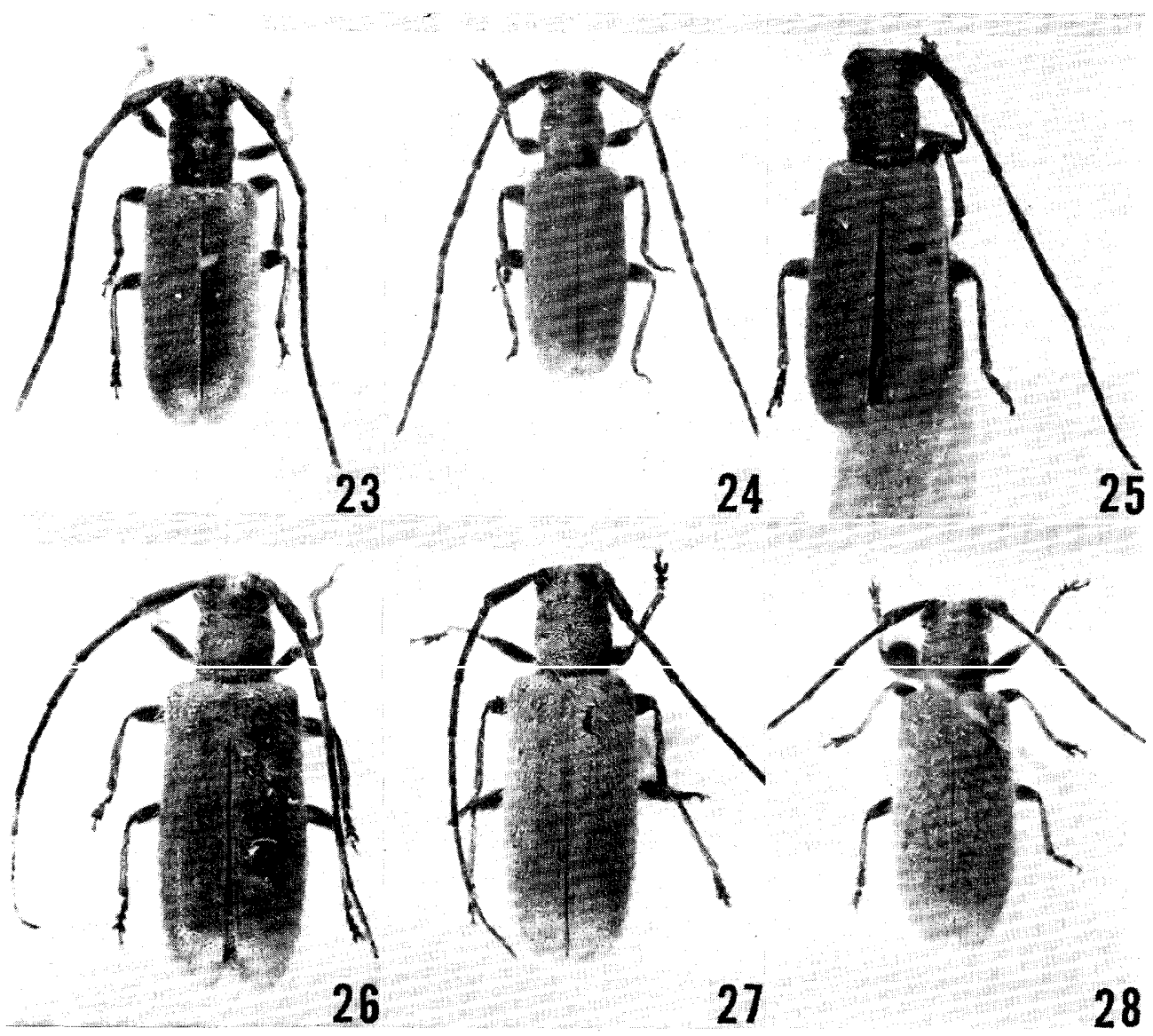

Figs. 23 \& 26. Penthides rufoflavus, 23. male, 26. female.

Figs. 24 \& 27. Penthides flavus multipubens subsp. nov., 24. male, 27. female.

Figs. 25 \& 28. Penthides flavus flavus, 25. male (holotype), 28. female.

2. Body blackish brown; head and pronotum with yellowish brown pubescence in male; head, pronotum and elytra with yellowish brown pubescence in female; head with sparse, short oblique blackish brown hairs in male; femora with depressed white pubescence ; Ishigaki I. and Iriomote I. of the Ryukyus.........

P. flavus multipubens subsp. nov.

- Body reddish brown; head and pronotum with short and slender pubescence in male; head, pronotum and elytra with dense, short and slender whitish yellow pubescence in male ; femora with short depressed yellowish white pubescence ; Taiwan

P. flavus flavus Matsushita

Length: Male 6-8 $\mathrm{mm}$, female $8-9 \mathrm{~mm}$.

Dtstribution: Ishigaki I. and Iriomote I. of the Ryukyus.

Type material: Holotype $\precsim$ (Type No. 2127, Kyushu Univ.), Mt. Omoto, Ishi. gaki I. of the Ryukyus, 30. v. 1975, N. Kanie leg. Paratypes o , Yonehara, Ishigaki I. of the Ryukyus, 11. v. 1967, Y. Yamawaki leg. ;2 우오, Nakara River, 
Iriomote I. of the Ryukyus, 25-28. vi. 1970, H. Makihara leg. ; $ð$, same data as holo type.

Type depository: The holotype is preserved in the collection of the Entomological Laboratory, Faculty of Agriculture, Kyushu University.

Note: This new subspecies was collected on leaves of Zanthoxylumailantoides $S$. et Z., Rutaceae.

\section{Tribe SAPERDINI}

\section{Glenea masakii sp. nov.}

Glenea chrysomaculata: Masaki, T. 1941, Coll. and Breed. 3(4): 199.

Body blackish brown ; femora, bases of tibiae and palpi reddish brown; tibiae except for bases, tarsi and mandibles dark reddish brown.

Body thick and stout.

Head as long as prothorax, punctured not densely, with sparse, oblique blackish brown hairs; vertex with two bands of depressed greenish yellow pubescence and scales; frons slightly convex, with depressed greenish yellow pubescence and scales, which becoming denser towards sides; labrum and basal portions of mandibles with slightly long depressed greenish yellow pubescence; gena with dense greenish yellow pubescence, inferior eye lobes to gena in length $4.5: 5.5$; antenna 1.3 times as long as body, relative length of each segment as follows: $3.0: 1.0: 5.0: 3.9: 3.9: 3.4: 3.0: 2.9: 2.9: 2.6: 3.0$, segments 1-6 with sparse, oblique brown hairs at ventral sides, segment 7 with oblique brown hair at dorsal apex, segments 1-3 and base of segment 4 with depressed whitish blue pubescece on ventral sides, segments 1-11 with oblique short brown pubescence except for the above mentioned parts.

Prothorax deeply punctured, with oblique blackish brown pubescence, and with sparse, erect blackish brown hairs, depressed greenish yellow pubescence and scales forming three stripes on each side and middle.

Scutellum trapeziform, with dense, depressed golden yellow pubescence and with sparse greenish yellow scales.

Elytra 2.3 times as long as head and prothorax combined, twice as long as broad; humeri developed and wide; apices slightly concave, with two projections on each side; disk heavily punctured at base, the punctures becoming weaker toward apex, with dense, depressed blackish brown pubescence, and with sparse, oblique blackish brown hairs, depressed golden yellow pubescence forming a complete stripe, four spots and an imcomplete stripe on each elytron.

Ventral side with dense, depressed golden yellow pubescence, and with oblique whitish yellow pubescence.

Legs stout; femora with erect reddish brown pubescence and oblique whitish yellow hairs; fore tibiae with depressed blue pubescence except for basal and dorsal sides, dense oblique short yellowish brown hairs on ventral sides, and sparse oblique brown bristles; mid and hind tibiae with depressed brown pubescence and oblique whitish yellow pubescence on ventral sides, with dense, oblique brown setae on dorsal of apices, with sparse, long oblique brown 


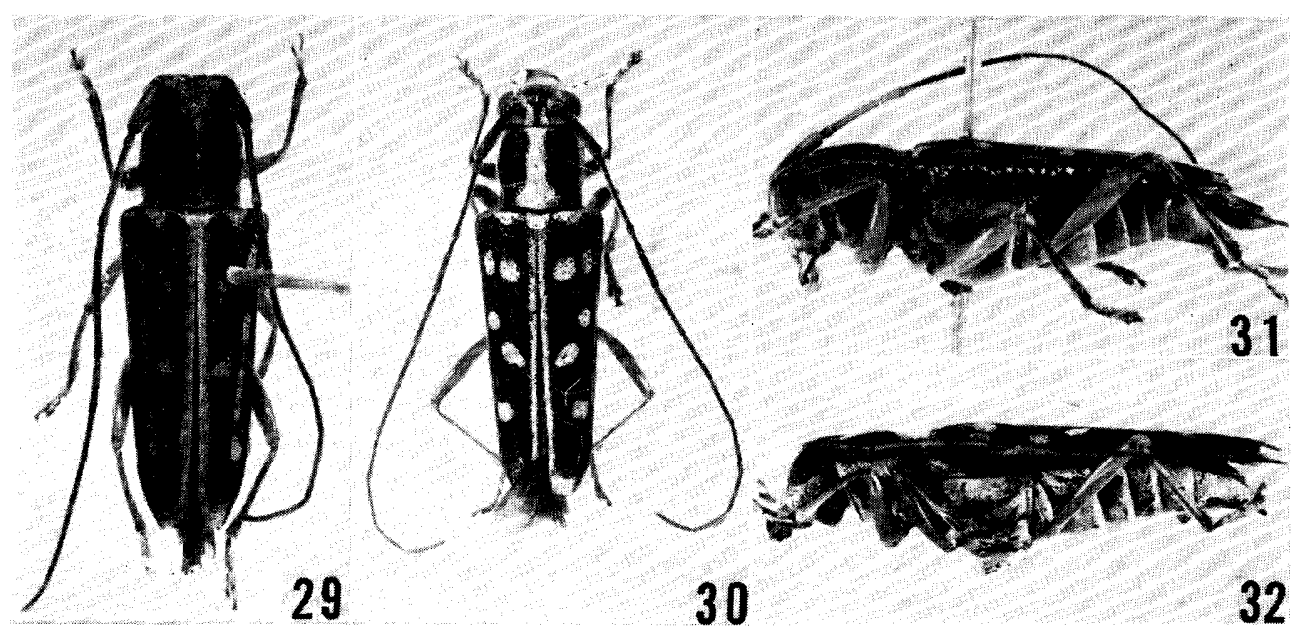

Figs. 29 \& 31. Glenea masakii sp. nov., female, 29. dorsal view, 31. lateral view.

Figs. 30 \& 32. Glenea chrysomaculata, female, 30. dorsal view, 32. lateral view.

hairs on lateral sides, and with conspicuous oblique golden yellow pubescence at middle of dorsal sides; tarsi with depressed blue pubescence on dorsal sides, dense oblique brown hairs on ventral sides, and sparse long oblique brown hairs.

Length : $13.5 \mathrm{~mm}$. Width : $4.5 \mathrm{~mm}$. Thickness : $4.5 \mathrm{~mm}$.

Distribution: Uotsurijima I., Senkaku Is. of the Ryukyus.

Type material: Holotype ㅇ (Type No. 2128, Kyushu Univ.), Uotsurijima I., Senkaku Is. of the Ryukyus, 26. v. 1939, T. Masaki leg.

Type depository: The holotype is preserved in the collection of the Entomological Laboratory, Faculty of Agriculture, Kyushu University.

Diagnosis: This new species is closely related to G. chrysomaculata Schwarzer from Taiwan, but is separable from the latter by the following points: Body stout and thick; elytral humeri well developed and elytra with golden yellow spots.

\section{References}

Bates, H. W. 1884. Longicorn Beetles of Japan. Jour. Linn. Soc.Zool., 18: 205-262.

Breuning, S. 1956. Revision der Gattung Glenea Newm. Ent. Arb.Mus. G. Frey, 7: I-199; 671-893.

-- 1958. Ditto., 9: 175-351; 804-907.

Ehara, S. 1954. Comparative anatomy of male genitalia in some Cerambycid beetles. Jour Fac. Sci. Hokkaido Univ. Ser. 6. Zool.,12(1-2): 61-115

Gressitt, J. L.. 1947. Notes on the Lepturinae (Coleoptera, Cerambycidae). Proc. Ent. Soc. Wash., 49(7): 190-192.

1951. Longicorn beetles of China. Longicornia 2: I-667, 22 pls.

, J. A. Rondon \& S. Breuning. 1970. Cerambycid-beetles of Laos. Pacif. Ins. Mon., $24: 1-651$.

Hayashi, M. 1957. Studies on Cerambycidae from Japan and its Adjacent Regions 7. Ent. 
Rev. Japan, $8(2): 45-48$.

1963. The Cerambycidae of Ryukyu Islands 2. Additions to the Cerambycid-fauna of Ryukyu Archipelago (Col.). Ent. Rev. Japan. 15(2): 50-55.

Kojima, K. \& M. Hayashi. 1969. Insect'slife in Japan 1. Cerambycidae: 1-295, 56 pls. Hoikusha, Osaka. (In Japanese)

Linseley, E. G. \& J. A. Chemsak. 1972. Taxonomy and classification of the subfamily Lepturinae 1. Cerambycidae of North America Part 6, No. 1. Univ.Calif. Pub. Ent. 69: l-138, 4 pls.

Masaki, M. 1941. Reserches on Senkaku Is. Collecting and breeding, 3(4): 102-111. (In Japanese)

Matsushita, M. 1933. Beitrag zur Kenntnis der Cerambyciden des japanischen Reichs. Jour. Fac. Agr. Hokkaido Imp. Univ. 34(2): 157-445, 5 pls.

Pic, M. 1922. Nouveautés diverses. Mél. Exot. Ent., 37: l-32.

Samuelson, G. A. \& J. L. Gressitt. 1965. The Cerambycidae of the Ryukyu Archipelago 1. Pacif. Ins., 7(1): 47-81.

Samuelson, G. A. 1965. The Cerambycidae of the Ryukyu Archipelago 2. Pacif. Ins., 7(1): 82: 130 .

Schwarzer, B. 1925. Sauter's Formosa-Ausbeute (Cerambycidae, Col.). Ent. Blätt. 2(4): 145-154. 